DOI 10.37882/2223-2982.2021.09.15

\title{
ОСОБЕННОСТИ СОЗДАНИЯ И ПРИМЕНЕНИЯ ФОРМИРОВАНИЙ МЕСТНОЙ ПРОТИВОВОЗДУШНОЙ ОБОРОНЫ В ПЕРВЫЕ МЕСЯЦЫ ВЕЛИКОЙ ОТЕЧЕСТВЕННОЙ ВОЙНЫ
}

\section{FEATURES OF CREATION AND APPLICATION OF FORMATIONS OF LOCAL ANTI-AIR DEFENSE IN THE FIRST MONTHS OF THE GREAT PATRIOTIC WAR}

\section{Lavrova \\ M. Arakelyan \\ A. Malov}

Summary: In the first months of the Great Patriotic War, the personnel of the local air defense made a significant contribution to achieving victory. Local air defense provided protection for the population, cities and important industrial facilities from air attack and artillery shelling. In addition to eliminating the consequences of bombing, fighting fires, and conducting emergency recovery operations, the local air defense forces were directly involved in combat operations and were involved in various special operations. The article discusses the features of the creation and use of local air defense formations during the Great Patriotic War.

Keywords: local air defense, local air defense troops, local air defense formations, self-defense groups, the Great Patriotic War.

\section{Лаврова Ирина Анатольевна}

К.и.н., дочент, ФГБВОУ ВО «Академия гражданской защиты МЧС России»

iralavrova@mail.ru

Аракелян Марина Александровна,

К.и.н., дочент, ФГБВОУ ВО «Академия гражданской защиты MЧС Poccuu»

koschka_1881@mail.ru

Малов Алексей Викторович,

К.ф.н., доцент, ФГБВОУ ВО «Академия гражданской защиты МЧС России» alexmatd@mail.ru

Аннотация: В первые месяцы Великой Отечественной войны личный состав местной противовоздушной обороны внес существенный вклад в достижение победы. Местная противовоздушная оборона обеспечивала защиту населения, городов и важных промышленных объектов от воздушного нападения и артиллерийских обстрелов. Помимо ликвидации последствий бомбардировок, борьбы с пожарами, проведения аварийно-восстановительных работ силы местной противовоздушной обороны принимали непосредственное участие в боевых действиях и привлекались в различных специальных операциях. В статье рассмотрены особенности создания и применения формирований местной противовоздушной обороны во время Великой Отечественной войны.

Ключевые слова: местная противовоздушная оборона, войска местной противовоздушной обороны, формирования местной противовоздушной обороны, группы самозащиты, Великая Отечественная война.

\section{группы самозащиты.}

Войска МПВО НКВД СССР включали в себя 3 инженерно-противохимических полка (в Москве, Ленинграде и Баку) и 4 инженерно-противохимических батальона [25]. Во время войны они представляли собой резерв главного командования и выполняли задачи по защите важных административных центров от воздушного нападения, осуществляли разминирование территорий, ликвидировали последствия бомбардировок и артиллерийских обстрелов.

Так, 3-й инженерно-противохимический полк МПВО НКВД СССР 27 июня 1941 г. был включен в систему МПВО г. Москвы и состоял в резерве главного командования. При приближении линии фронта к столице полк был включен в состав действующей армии и задействован при строительстве оборонительных рубежей. Также он проводил работы по извлечению и обезвреживанию неразорвавшихся авиационных бомб как в Москве, так и в 
городах Московской, Тульской, Ярославской, Рязанской, Калининской (Тверской) и Ивановской областей [1, С.1617].

Помимо этого, войска МПВО осуществляли инженерное обеспечение действий частей Красной Армии и принимали непосредственное участие в боях. К примеру, одна их воинских частей МПВО НКВД СССР, дислоцирующаяся в начале войны в Минске, после сдачи белорусской столицы совместно с войсками Западного фронта вела оборонительные бои под Могилевом, Смоленском, Ярцевом, Вязьмой. В октябре 1941 г. эта часть была переведена в Горький (Нижний Новгород), где выполняла задачи по защите города от воздушного нападения немцев [20].

Можно предположить, что речь идет о 22 отдельном инженерно-противохимическом батальоне войск МПВО НКВД СССР. 29 июня 1941 г. этот батальон находился в оперативном подчинении начальника Управления охраны войскового тыла Западного фронта [24]. В дальнейшем батальон был переведен в г. Горький.

Стоит отметить, что подразделения войск МПВО НКВД СССР, находящиеся на западных рубежах нашей страны, по мере продвижения противника переводились в глубокий тыл для защиты важных административных центров от воздушного нападения. Например, 31 отдельный инженерно-противохимический батальон войск МПВО НКВД СССР, располагавшийся в г. Запорожье, после тяжелых боев второй половины 1941 г. был отправлен на доформирование и в июле 1942 г. направлен в Сталинград [8], где находился в оперативном подчинении отделения МПВО Управления НКВД по Сталинградской области [14].

В связи с тем, что войска МПВО НКВД СССР были немногочисленны, то большую роль в деле защиты населения от действий немецкой авиации сыграли невоенизированные формирования местной противовоздушной обороны (команды местной ПВО и группы самозащиты), которые и представляли основу сил МПВО.

Уже с первых часов войны они приступили к выполнению боевых задач.

Так в г. Гродно Белорусской ССР 22 июня 1941 г., спустя 45 минут после начала бомбардировки города, на свои рабочие места прибыл весь личный состав команд МПВО, которые сразу же были направлены в очаги поражения. В 5 часов утра они работали на 6 пунктах города по ликвидации пожаров и извлекли из-под развалин 34 трупа и 16 человек раненых [2, С. 390-391].

Для ликвидации последствий воздушных налетов, восстановления жизнедеятельности разрушенных промышленных объектов, важных железнодорожных узлов, лечебных учреждений по решению советского правительства началась работа по развертыванию подразделений МПВО. В стране стали создаваться новые части МПВО (кадровые и городские), различные формирования МПВО в промышленности, на транспорте, в медицинских учреждениях и жилом секторе [22, С. 17.]

В соответствии с постановлением Государственного комитета обороны от 9 июля 1941 г. «Об образовании в местностях, объявленных на военном положении, городских аварийно-восстановительных отрядов» на базе строительных трестов и управлений, ремонтных служб исполкомов местных Советов стали создаваться подразделения МПВО [15, С. 215.].

Они формировались как военизированные отряды и части МПВО. Так, в Харькове и Днепропетровске были созданы аварийно-восстановительные полки; в Ворошиловградской (Луганской) области - батальон в областном центре и 4 роты в районах; в Днепродзержинске (Каменском) и Кривом Роге - по батальону, а в других городах аварийно-восстановительные роты. В Полтаве 12 июля 1941 г. были созданы 40 аварийно-восстановительных отрядов, два батальона и одна рота МПВО [4, С.43].

В Одессе также был образован аварийно-восстановительный полк. В Симферополе 11 июля 1941 г. на базе строительных и ремонтных контор, жилищных управлений и дорожного комбината был организован аварийно-восстановительный батальон МПВО, состоящий из дорожно-мостовой (142 чел.), технической (97 чел.), строительной (142 чел.) рот и взвода подрывников (19 чел.) [11, С. 42].

10 июля 1941 г. в соответствии с постановлением объединённого заседания бюро Краснодарского крайкома ВКП(б) и крайисполкома № 77 в трёхдневный срок были созданы подразделения МПВО в крупных городах: двух батальонов в Краснодаре и по отдельной роте в Новороссийске, Туапсе, Армавире [19, С. 215-216].

В Мурманске решением Мурманского облисполкома от 12 июля 1941 г. на базе «Облстройтреста» был создан аварийно-восстановительный батальон МПВО, а в городах Кировск и Кандалакша - аварийно-восстановительные роты [19,С.20-21,215-216]. В дальнейшем в Мурманске приказом НКВД СССР от 26 марта 1943 г. был сформирован 362-й отдельный городской батальон МПВО, который содержался за счёт местного бюджета [6, C. 56-57].

11 июля 1941 г. в соответствии с постановлением Калининского исполкома областного совета и бюро обкома «О создании аварийно-восстановительных отрядов МПВО» на базе ремонтно-строительных контор началось формирование 13 отрядов. Они предназначались 
для восстановления жилых домов, больниц, школ, предприятий коммунального хозяйства, энергетики, связи, дорог и мостов. Эти подразделения должны были быть военизированными и переводились на казарменное положение. Обеспечение формируемых отрядов необходимым оборудованием, инструментом, транспортом, строительными материалами, помещениями для размещения личного состава, питанием и необходимой спецодеждой находилось в ведении председателей исполкомов горсоветов и секретарей горкомов ВКП(б).

В Калинине (Твери) на базе контор «Дорстрой» и «Водоканализация», а также аварийно-восстановительных служб электрокомбината, конторы связи и трамвая был создан ремонтно-строительный батальон в составе двух общестроительных рот, санитарной роты, дорожностроительного и трех отдельных спецвзводов (энергетика, связь, трамвай).

В Калуге на заседании бюро Калужского горкома ВКП(б) и горисполкома 15 июля 1941 г. было принято решение о создании к 17 июля на базе Горстройконторы аварийно-восстановительного отряда МПВО из 300 чел. Отряд состоял из взводов: ремонтно-строительного электропроводки, ремонта водопровода и канализации, ремонта пути и ремонтно-строительного.

25 июля 1941 г. на заседании бюро Калужского горкома и горисполкома было принято решение сформировать в г. Калуге аварийно-восстановительный батальон МПВО [7, С. 188-198].

В Орджоникидзевском (Ставропольском) крае в июле 1941 г. решением краевого штаба МПВО на базе городских и районных строительных организаций было образовано 2 батальона МПВО в Ворошиловске (Ставрополе), а на Кавказских Минеральных Водах - отдельные роты [12, С. 108-110, 112].

В г. Курске в августе 1941 г. были сформированы и переведены на казарменное положение 3 аварийновосстановительных отряда (отряд общестроительных работ - 100 чел., отряд по дорожному строительству 20 чел., отряд по восстановлению водопроводной сети и связи - 20 чел.) [13, С. 88].

В Воронеже в декабре 1941 г., когда город был определен городом-пунктом ПВО, был образован аварийновосстановительный полк [21, С. 21].

Bce эти подразделения создавались по решению областных и местных органов власти, находились в их подчинении, оснащались за счет бюджетов областей и городов. Непосредственное управление формированиями МПВО осуществляли городские и районные штабы МПВО, а руководство - чрезвычайные органы управле- ния (Государственный комитет обороны и городские комитеты обороны).

Например, в Москве в целях усиления системы МПВО столицы постановлением Государственного комитета обороны 5 июля 1941 г. были созданы 4 полка, 1 отдельный батальон и 2 отдельные роты МПВО численностью 11300 человек.

В соответствии с этим постановлением были образованы следующие подразделения:

- 1-й полк по восстановлению зданий и ликвидации последствий завалов (5830 чел., 19 экскаваторов, 370 автомашин, 34 компрессора, 14 тракторов, 14 передвижных электростанций, 9 автокранов);

- 2-й полк по восстановлению дорог и мостов (1000 чел., 7 экскаваторов, 6 катков, 5 бульдозеров и тракторов, 50 автомашин);

- 3-й аварийно-восстановительный водопроводноканализационного хозяйства полк (1760 чел., 11 экскаваторов, 80 автомашин, 258 насосов);

- 4-й аварийно-восстановительный полк по энергетическому хозяйству (1590 чел.);

- отдельный аварийно-восстановительный батальон по газовому хозяйству (450 чел., 21 грузовая машина);

- отдельная специализированная аварийно-восстановительная рота связи (80 чел.).

При этом участковые команды МПВО г. Москвы были реорганизованы в 25 батальонов, находящихся при районных штабах МПВО (23800 чел.).

Обеспечение этих подразделений помещениями, автомобильной и инженерной техникой было возложено на Моссовет [39].

7 июля на заседании исполкома Моссовета было принято решение сформировать указанные подразделения МПВО численностью 35167 чел. и разместить их с 8 июля в казармах [10, С. 21, 23-25, 29, 33, 36].

Эти полки формировались на базе московских городских служб [16, С. 26]. Например, Аварийно-восстановительные полки формировались на базе строительных организаций Моссовета [23, С. 66]. А Управление водопроводно-канализационного хозяйства г. Москвы было реорганизовано в 3-й полк МПВО [18, С. 215]. В системе Мосэнерго был сформирован 4-й полк МПВО [19, С. 10].

Рядовой и командный состав этих полков комплектовались из числа работников соответствующих городских служб. Так, 3-й аварийно-восстановительный водопроводно-канализационного хозяйства полк возглавил начальник Управления водопроводно-канализационного хозяйства г. Москвы. Командирами батальонов были 
управляющие трестами «Мосводопровод» и «Мосочиствод», командирами рот - начальники водопроводных станций $[17$, С. 9].

Кроме того, для борьбы с пожарами в Москве были подготовлены 12736 специальных противопожарных команд на предприятиях и в учреждениях, комсомольско-молодёжный полк, противопожарные звенья в группах самозащиты. Для оказания медицинской помощи пострадавшим, кроме использования существующих лечебных учреждений, привлекались 5000 санитарных дружин на предприятиях, 36 медико-санитарных рот отдельных городских батальонов, 127 травматологических отрядов [18, С. 397]. Вся группировка формирований и подразделений МПВО в Москве составляла порядка 650 тысяч человек [3, С. 10].

В созданный для защиты Петрозаводска сводный истребительный отряд входила рота МПВО (250 чел.), которая держала оборону в районе деревень БесовецВиданы с 24 сентября по 30 октября 1941 г. В ходе оборонительных боев погибло 7 и было ранено 49 воинов МПВО [19, С. 158-159].

2 июля 1941 г. Советом Народных Комиссаров СССР было утверждено Постановление о всеобщей обязательной подготовке населения к противовоздушной обороне. В нем определялось, что все население страны (женщины в возрасте от 18 до 50 лет, а мужчины - от 16 до 60 лет) обязано было привлекаться к работе в составе групп самозащиты МПВО на предприятиях, в учреждениях и жилых домах. Порядок подготовки и организации групп самозащиты устанавливался решениями правительств союзных республик [5, С. 5].

В годы Великой Отечественной войны система Местной противовоздушной обороны приобрела общегосударственный характер, и подразделения МПВО стали создаваться в большинстве городов глубокого тыла. Так, при штабе МПВО Ярославля 18 июля 1941 г. был образован батальон МПВО в составе: двух рот по ликвидации завалов и восстановлению разрушенных зданий (200 чел.); взводов ликвидации аварий нарушения водопровода и канализации (30 чел.), дорожно-мостовых работ (50 чел.), ликвидации аварий трамвая (60 чел.); отделения ликвидации аварий энергохозяйства (20 чел.) [7, С. 198-204].

В Тамбове к началу декабря 1941 г. на базе строительных и коммунальных учреждений была сформирована аварийно-восстановительная команда (подразделения по восстановлению разрушенных зданий и ликвидации завалов - 57 чел.; водопроводно-канализационного хозяйства - 30 чел.; энергохозяйства - 20 чел.; мостов и дорог - 16 чел.).

В городе Златоусте Челябинской области в октябре 1941 г. - сформированы участковые формирования МПВО из числа военнообязанных и объектовые команды на предприятиях [9].

Городские команды и отряды МПВО формировались на базе городских служб. Для эффективного решения задач по защите населения и территорий от воздушных налетов и артиллерийских обстрелов в ходе войны данные формирования военизировались и имели структуру воинских подразделений.

В годы Великой Отечественной войны, помимо ликвидации последствий бомбардировок, восстановления разрушенных объектов, борьбы с пожарами, оказания медицинской помощи и разминирования подразделения МПВО привлекались к выполнению неспецифических задач, таких как борьба с диверсантами, участие в операциях по уничтожению бандформирований и в боевых действиях.

На сегодняшний день опыт создания и применения сил МПВО в годы Великой Отечественной войны не потерял своей актуальности и может быть использован при создании специальных формирований, предназначенных для решения задач гражданской обороны в военное время.

\section{ЛИТЕРАТУРА}

1. 80 лет службы Отечеству. 1936-2016. / под общ. ред. В.А. Пучкова. - М.: ФГБУ ВНИИ ГОчС (ФЦ), 2016. - 226 с.

2. 1941: документы и материалы: к 70-летию начала Великой Отечественной войны : в 2 т. / [сост.; Ю.А. Никифоров, к. и. н., и др.]. Т. 2. — СПб.: ФГБУ «Президентская библиотека имени Б. Н. Ельцина», 2011. — 575 с.

3. Алексеев И. Выстояли и победили. // Гражданская защита. - 2017. - № 5(501). - С. 9-11.

4. Беляев А.Н. Местная противовоздушная оборона страны в Великой Отечественной войне 1941-1945. - М.: Военное издательство, 1985. - 232 с.

5. Бревдо Ф.И. Организация местной противовоздушной обороны. / Изд. 2-е. под общ. ред. инженер-полковника Б. Трамма. - М.: Редиздат ЦС Осоавиахима, 1944. -20 c.

6. Гоцюк В.Г. Местная противовоздушная оборона Мурманской области в период 1918-1945 гг.: учебное пособие для студентов высших учебных заведений. - Мурманск: Изд-во МГтУ, 2012. - 66 с.

7. Гусев А.В. Местная противовоздушная оборона областей центрального района России в предвоенный период и в годы Великой Отечественной войны 
(1932 - 1945 гг.). Дис. доктора ист. наук. - Кострома: Костромской государственный технологический университет, 2014. - 442 с.

8. Иван Устинович Харченко [Электронный ресурс]. Режим доступа: https://ru.wikipedia.org/wiki/\%D0\%A5\%D0\%B0\%D1\%80\%D1\%87\%D0\%B5\%D0\%BD\%D0 \%BA\%D0\%BE,_\%D0\%98\%D0\%B2\%D0\%B0\%D0\%BD_\%D0\%A3\%D1\%81\%D1\%82\%D0\%B8\%D0\%BD\%D0\%BE\%D0\%B2\%D0\%B8\%D1\%87\#cite_note-3 (дата обращения: 15.03.2021).

9. История развития гражданской обороны в г. Златоусте. [Электронный ресурс]. Муниципальное казенное учреждение Златоустовского городского округа «Гражданская защита». Режим доступа: https://gzzgo.ru/history/ (дата обращения: 15.03.2021)

10. Комаров Н.Я. Куманев Г.А. Великая битва под Москвой: Летопись важнейших событий. Комментарии. - М.: Институт российской истории РАН, 2002. 339 c.

11. Крым в период Великой Отечественной войны: 1941-1945 гг.: сборник документов и материалов. / Отв. ред. М. Р. Акулов. - Симферополь: Таврия, 1973. -487 c.

12. Крюкова Л. В. Становление и развитие местной противовоздушной обороны (МПВО) на Ставрополье: 1930-е - начало 1960-х годов: диссертация кандидата исторических наук. - Пятигорск, 2010. - 209 с.

13. Курская область в период Великой Отечественной войны Советского Союза 1941-1945 гг.: Сборник документов и материалов в 2 т. Т. 1. 22 июня 1941 г. март 1943 г. - Курск: Курское книжное издательство, 1960. - 487 с.

14. Лагодский С.А. Сталинград: подвиг солдата правопорядка. - М.: Объединенная ред. МВД России, 2013. - 487 с.

15. Лебедев А.В. Спасательное дело в России. Под ред. В.А. Пучкова. - М.:. ФГБУ ВНИИ ГОчС (ФЦ), 2014. - 252 с.

16. Люди и дела Гражданской обороны. - М.: Воениздат, 1974. - 152 с.

17. Мосводоканал в Великой Отечественной войне. // Водоснабжение и санитарная техника. - 2010. - № 5 - С. 9 - 15.

18. «Москве - воздушная тревога!». Местная ПВО в годы войны: Сборник / Сост. Ю.Ю. Каммерер, В.С. Караулов, С.Е. Лапиров. - 2-е изд., доп. и перераб. М.: Моск. рабочий, 1991. -471 с.

19. От МПВО к гражданской защите. Страницы из истории МПВО - ГО - РСЧС субъектов Российской Федерации / сост. В.А. Владимиров, Н.Н. Долгин, Ф.Г. Маланичев; МЧС России. - М.: Ин-октаво, 2004. - 352 с.

20. Сафронов П. Части МПВО в годы Великой Отечественной войны. / Воин МПВО. - 1959. - 30 мая. - № 22 (46)

21. Симонов А.П. Служба спасения: разные судьбы: документальные очерки. - Воронеж: Воронежский государственный университет, 2005. - 448 с.

22. Томарев Н. История, назначение и боевые традиции войск МПВО. // На боевом посту. - 1959. - № 5. - С.16-19.

23. Турапин Е.А. Деятельность невоенизированных формирований Местной противовоздушной обороны Москвы в годы Великой Отечественной войны 1941-1945 гг. диссертация ... кандидата исторических наук: 07.00.02. - Москва, 1986. - 385 с.

24. Управление войск НКВД по охране тыла Западного - 3-го Белорусского фронта. [Электронный ресурс]. История отечественных спецслужб и правоохранительных органов. Режим доступа: http://shieldandsword.mozohin.ru/VD3462/troops/vot/west.htm (дата обращения: 15.06.2020)

25. Успенский И.В. Документальные материалы РГВА по истории Великой Отечественной войны 1941-1945 гг. [Электронный ресурс]. Российский Государственный Военный Архив. Режим доступа: http://rgvarchive.ru/iv-uspenskii-glavnyi-spetsialist-dokumentalnye-materialy-rgva-po-istorii-velikoiotechestvennoi-voin (дата обращения: 15.06.2021) 